\title{
A Qualitative Inquiry from the Aegean Region: Changing Ruling Class in Business Circles
}

\author{
Ela Burcu Uçel*
}

Alev Katrinli**

\begin{abstract}
This paper aims to examine the Turkish ruling class in business circles and to detect possible changes that might have occurred in the past ten to fifteen years. In the 2002 general elections, the ruling political party changed, and an Islamicoriented party, AKP (Justice and Development Party), secured office. The following years presented observable changes in the Turkish political life, which may have caused related changes in the ruling class profile of the business circles in the country. In the aftermath of these changes, the current study attempts to portray the present ruling class of business in Turkey from an Aegean perspective. A series of in-depth interviews were conducted with carefully selected actors of the business, political and academic circles from the Aegean Region. The findings exhibited a change in the ruling class profile in business circles and presented a description of this class.
\end{abstract}

\section{Keywords}

Ruling class, business, politics, Turkey, İslamic Capital, woman

İzmir University of Economics - İzmir / Turkey

elaburcy@yahoo.com

** Prof. Dr., İstanbul Aydin University, Faculty of Economics and Administrative Scrences - Istanbul / Turkey katrinli.alev@gmail.com 


\section{Introduction}

Turkish ruling class tradition goes back to the Ottoman Empire where the ruling class was composed of bureaucracy and army (İnalcik 1964: 42-45) and those who were widely dominant in trade and production: NonMuslims; and it continues with the foundation of the republic in 1923 when a new ruling class was intentionally created by the liberators of the country. After a transition period from the Non-Muslim citizens' domination of the ruling class in business circles, Atatürk and his companions purposefully chose those people who were well educated, who had faith in the new republic, in modernity and charged them with the duty of establishing trade and industry in this collapsed country that survived the independence war. After Atatürk's death, several parties ruled the country but the ruling class of the business circles maintained its position (İnalcik 1964: 42-63).

This very ruling class has been facing a stern and unsettling period recently. The reasons that created this unsettling period can be summarized in just a few words by Lorasdağı (2010: 106)

"The impact of the globalization processes and the related changes in Turkish political, economic and cultural life paved the ground for the resurgence of Islam in Turkey in the 1990s. It also altered the nature of Turkish modernity which is staunchly defined within the framework of western modernization that shaped the state's stance against religion as strictly secular."

With the ever increasing power of Islamic ideology and political groups in the country, AKP (Justice and Development Party) has secured office in 2002. That year was the beginning of "the new times". After years of convenient domination and a standalone rule, ruling class members found themselves in a struggle to keep their positions. The new entrants, Islamic capital groups, were carrying out planned and disciplined endeavors; thus there was an apparent struggle of domination in the country.

The increasing power and impact of Islamic capital groups and political parties created an interest in academic studies focusing on these groups. This study, in the light of above mentioned changes in the country, aimed to investigate the present ruling class and the struggle for its domination with a perspective from the Eagean Region, and to contribute the literature by providing information about its changing nature. 


\section{Relevant Literature}

As the focus of this study is the ruling class in Turkish business circles, only those parts of the literature, that fit the topic will be covered. The paper will take a business focused approach on the issue rather than taking a broad sociological perspective. Thus, the flow of literature that complies with the general stream of this paper will include the emphasis of two main concepts: first, stratification and class, then the dominant ideology thesis which guides the reader to the concept of ruling class.

The concepts "Class" and "Stratification" have long been studied in sociology by major academicians and thinkers like Marx (1968), Weber (1979), Wright $(1978,1985,2000)$ and Goldthorpe (1968). There is also a vast literature about the topic in other academic fields.

Giddens (1987: 9) defines Weber's (1979) and Marx's (1968) “Stratification" as structural inequalities in separate groups formed by people. He argues that the society can be viewed as layers composed of people who stand close to the base of the society and have few privileges and those who stand at the top of the society and have many privileges. Giddens (1987: 9) also gives a brief and sound definition to class, according to him class refers to big lots of people who share general economic sources that influence the life styles that they can head towards.

According to Marx and Engels' (1979: 64-65) first theory of ideology, different social classes have different stakes depending on their degree and nature of involvement with the "means of production", thus they each constitute their own sets of beliefs. Their second theory of ideology states that society's economic frame assigns, determines the superstructure of politics and economics. Marx and Engels (1979: 64-65) argue that the dominant class enjoins its set of beliefs to subordinate classes, this practice prevents reformist thoughts. As a result, the system that serves the stakes of the dominant class is maintained and sustained.

On the other hand, according to the ruling ideas model, the ruling class governs not only the means of production but also the means of intellectual production and thus ensures the expansion of own beliefs to other classes (Aron 1950: 2-5, 9-14). In addition to holding means of production and the means of intellectual production, (Aron 1950: 2-5, 9-14) suggests that the ruling class obviously holds a greater power compared to the political ruling party in democratic regimes because they control greater economic and political sources. As for the state-ruling class involvement and relationship, a group of conflicting ideas exist in the literature. Block 
(1977: 8-9) states that the Orthodox Marxist Theory is denounced by instrumentalists (Miliband 1969) of accepting the state as merely a tool that ruling class uses to maintain power. He presents counter ideas, the state is in a position to behave neutral in order to maintain social order and protect legitimacy. It also has to ensure the sustainability of the capitalist system thus it can not afford to work for the stakes of a certain capitalist group.

Poulantzas $(1973: 11-33,1975)$ in critisizing Miliband, argues that state is neither the instrument of the ruling class nor is totally independent and neutral. According to him, state is not directly linked to the capital; but there are objective structural relations between them.

For Relative Authonomy Theory, state is partly autonomous from the ruling class (Poulantzas 1973: 11-33, 1975).

The relative autonomy theorists also argue that when the state starts to abuse this condition of relative autonomy, ruling class counteracts actively by lobbying, donations, recruiting ruling class representatives to government positions, influencing policy making processes and favors to political parties and government employees (Miliband 1969: 5-7, 150-153, Poulantzas 1973: 11-33, 1975).

On the other hand, the dominant ideology thesis, as explained by Abercrombie and Turner, (Abercrombie et al 1978: 151-155) offers an explanation for the maintenance of classes: In order to prevent the progress of political opposition, a certain group of ideas and beliefs dominates all others. By adopting the subordinate classes to these beliefs and by fixing these beliefs to their consciousness, radical opposing ideas are avoided.

In contrast with this theory, Abercrombie and Turner (1978: 153-160) suggest that subordinate classes are not incorporated to these beliefs themselves. The dominant classes create and diffuse these beliefs. In most societies, dominant beliefs are not successfully accessed to subordinate classes due to the ineffective use of transfer mediums. Instead, they are headed to the dominant classes. Back in the era of feudalism, there were no available mediums, but with the emergence of the capitalist system, such institutionalized mediums came into use like the education system. The main idea behind this set of dominant beliefs and transfer mediums to expand them is to sustain and protect the dominant class power on economy and property. Thus, these beliefs render service to the stakes of the dominant class. In fact the very capitalist system demands such a set of beliefs in order to guarantee the maintenance of dominant class mastery. 
As for the ruling class, it is defined by Domhoff (1999: 267), as a social upper class and its certain characteristics are sorted as it:

- Holds a disproportionate part of wealth

- Has higher life standards than other social groups

- Controls and manipulates fundamental national economic institutions

- Has dominance over political processes of that country

Domhoff (1999: 275) also describes the determination of the ruling class to disseminate own belief systems as "...members of the ruling class work very hard at helping us to accept their view of the world. Indeed, we can be sure from past experience that they will stop at nothing...”.

It is also referred in the literature that, like in any other "class", the members of the ruling class can change in time. The order of classes is changeable (Giddens 1987: 9-10). People may alter their placements. Pareto (1935: 1419, 1421, 1424) suggests that in any social order a certain minority uses power and this is an indispensable condition. Sometimes the profile of this minority changes and the power is passed to another group, but no matter what, that certain minority always exists. That minority captures significant critical points and arranges the distribution of wealth in favor of themselves. As Aron (1950: 9) states "Power never can be in the hands of millions of men. There is government for the people; there is no government by the people".

Ottoman/Turkish Ruling Class: As the current study aims to examine the ruling class in Turkish bussiness circles; the historical evolution of this class is briefly presented: The Ottoman Empire was founded at the end of the 14 th century and it had its brightest days in the 15 th century. Although it was one of the greatest empires of its time, it started to loose ground in 16th century and kept on loosing its power until the 19th century (Kongar 1998). The empire had a power which was based on religion and tradition. A delicate balance kept its power, a centralized bureaucracy which is totally disconnected from the public was at work. The Muslim public was not supposed to own property, as property meant wealth and wealth meant political power which may lead to opposition. Thus, almost all commercial activity was left to the Non-Muslim citizens (Bulut 2012: 64), who were naturally non-threatening for the sultanate because of their origins and religion. Hereby, the elite of the Ottoman was almost only non-Muslims, mostly Non-Muslims citizens were trading and they were dominant in trade, capital and economics (Heper 2000: 63-82). 
After the independence war and after the foundation of the young republic of Turkey in 1923, Atatürk and his companions formed a new elite by providing commercial privileges to Muslim citizens (Heper 2000: 63-82).

Thus, the history of Turkish ruling class in business circles presents a series of changes and underlying dynamics from the Ottoman times to present. The current struggle for this class is a major interest for this study. Thus, it attempts to detect any changes that may have occurred in the ruling class in Turkish business circles in a certain period of time with a look mainly from the Eagean Region; it aims to:

- Investigate the nature of the ruling class in business circles

- Detect changes that might have occurred in the composition of this class in a certain period of time

- Determine the reasons of those possible changes

\section{Methodology}

In this study, qualitative research methods were chosen to reach the research objectives. During the research process, overriding importence was given to ensure that the study reaches to an in-depth understanding of the "ruling class" and related dynamics; it obtains a view of the issue from the ruling class members' and other related parties' stand points. This view is captured from the Eagean Region. Individual in-depth interviews were conducted which allowed intensive respondent probing. During the interviews, personal biases are avoided in order to be open to diverse ideas, to look and check for opposite ideas and try to understand respondents' hidden agendas, feelings and fears (Ger 2009: 1-19).

During the research, eight in-depth interviews were conducted. No further interviews were made because respondents presented similar ideas and thoughts. Each respondent had more than fifteen years of job experience and held effective positions in their professions. After a few interviews, the transcriptions showed that almost all respondents tended to determine a certain direction of change in the ruling class: Increasing Islamic capital domination. Thus, in order to ensure multiplicity and triangulation (Ger 2009: 1-19, Spiggle 1994: 493-496), some respondents who were close to Islamic groups were selected and interviewed.

All interviews were conducted at the places determined by the respondents. As a result of their important and critical positions in their professions, participants had time constraints and heavy daily work loads; some of the respondents were unable to spare long time frames for the interview. Thus, duration of the interviews ranged from 25 minutes and 75 minutes. 
For certain interviews, this was a limitation. Due to the sensitive nature of the subject, most respondents were uncomfortable at the beginning of the interview. Even one respondent refused the use of a tape recorder. Thus that interview was included in the analysis by using the data obtained from researcher's field notes and memos. All other interviews were tape recorded and transcribed by the researcher. The selected quotations were translated from Turkish to English. In the very first interview, as a result of the first amateur attempt of the researcher, tape recorder was broken and most of the interview was lost. Remaining recordings, field notes and summary notes of the researcher were included in the analysis. In the following interviews, two tape recorders were used simultaneously.

The questions selected from the following inquiries were directed to the respondents:

- Do you think that a prominent ruling class exists in the Turkish business circles?

- What are the dynamics that shape this class?

- Do you observe any changes in this class regarding the past 10-15 years? (If yes) Can you tell me about this change?

- Are there any tools that the ruling class uses to sustain its power?

- What is women's position in the ruling class?

These questions were supported by probes and respondents were asked to share their personal experiences about the topics. In one interview, respondent started transferring his ideas in such a flow that, no further questions were needed to ask.

As stated in the literature, data collected during research were not comprised only of the responses of the respondents, but it also contains field notes and impressions of the researcher. Some descriptive information about the respondents is presented below. All respondents were assigned nicknames for confidentiality, as the purpose is not to expose personal information about the respondents but to present common and diverse ideas and experiences about the topics. 
Table 1. Respondents' Background Information

\begin{tabular}{ll}
\hline $\begin{array}{l}\text { Nickname and age of the } \\
\text { respondent }\end{array}$ & Profession \\
\hline Sinan, male, 68 & $\begin{array}{l}\text { Former CE0 of a number of big nationwide corpora- } \\
\text { tions, Doyenne Businessman }\end{array}$ \\
\hline Kemal, male, 34 & $\begin{array}{l}\text { Businessman in Textile Industry, } \\
\text { Vice president of a national businessmen association }\end{array}$ \\
\hline Nazan, female, 46 & Former diplomatist for The Turkish Government \\
\hline Perran, female, 46 & $\begin{array}{l}\text { Businesswoman, Academician, } \\
\text { Former strategic marketing research director of an } \\
\text { MNC in Turkey }\end{array}$ \\
\hline Salih, male, 52 & $\begin{array}{l}\text { Brand and patent consultant, } \\
\text { Serves some of the major corporations of the region, } \\
\text { Writer (Politics, International Relations and Commerce) }\end{array}$ \\
\hline Kerem, male, 59 & $\begin{array}{l}\text { Businessman, Politically active, President of Chamber of } \\
\text { Commerce of one of the biggest cities of he country }\end{array}$ \\
\hline Seyhan, male, 62 & $\begin{array}{l}\text { Doyenne Businessman, } \\
\text { Factory owner in woven goods sector, }\end{array}$ \\
\hline
\end{tabular}

During the data analysis process, following the guidelines offered by Spiggle (1994: 493-496), each transcription was read numerous times, going back and forth. During these readings, common and differential themes were detected and noted. The transcriptions were carefully analyzed to compare the common and differential findings. As stated above, in addition to transcriptions, field notes, memos and personal impressions of the interviewer were included in the analysis as encouraged by the literature (Spiggle 1994: 493-496, Ger 2009: 1-19). After the analysis was completed, findings were abstracted in three basic themes and under those themes, subthemes were organized. At this point, to ensure avoiding biases, the researcher applied introspection and thought of her ideas and possible biases about the subject for a period of time, and then re-controlled the analysis.

\section{Findings}

The multiple and well-rounded analysis of transcriptions presented certain common and differential themes. These themes lead us to three basic topics about the subject of inquiry:

- The nature of the ruling class as perceived, described and defined by the respondents 
- The changes in the ruling class members' profile as observed by the respondents

- The state-ruling class involvement (which is motivated by the desire of ruling class members to sustain their positions) as seen and perceived by the respondents

The following sections are organized according to those three topics.

A. Nature of the ruling class: All respondents tend to agree upon the existence of a prominent ruling class in Turkish business circles. They all, in some way or another, have defined and described the profile, dynamics and nature of this class.

The similarities and differences fell under the following issues:

- The existence and definitions of the ruling class

- Tools used by the ruling class to sustain power and influence

- Women's (under) representation

- The dynamics that shape the ruling class

The existence and definitions of the ruling class: All respondents delivered opinion in favor of the existence of a prominent ruling class in Turkish business circles, which was an anticipated result. Most of them tended to agree upon the definition and description of this class.

In fact, I guess, this would be a correct definition I think, the group which is able to direct and influence economics, politics and even social tendencies... (Nazan, diplomatist)

This definition, similar to others offered by different respondents, shows perceptions about the ruling class. Most of the interviews gave the impression that respondents had a feeling of their lives being directed by the third parties - ruling class. Virtually none of them refused the existence of a dominant ruling class in the business circles. They unwittingly concurred with Pareto (1935: 1419, 1421, 1424) as he claimed in any society a minority practices power indispensably. These responses also confirmed the Dominant Ideology Thesis as (Abercrombie et al 1978: 151-155) state it: "to direct and influence economics, politics and even social tendencies"

"directing even the social tendencies" implies that the ruling class incorporates its own beliefs and even its own life style through relevant medium and affect people's lives. 
Although the respondents agreed upon alike definitions, their descriptions were various and reflecting their own points of view as given in the next quotation.

What we call as the ruling class is the group that was positioned at the fountain of water earlier, they are a group of people, some has disappeared in time; some are still there, a group that rises as a result of the ruling political party, I characterize them as the group that was able to catch a position to itself in the globalization process. (Kemal, businessman)

Kemal's definition of the ruling class points to the state-ruling class interconnectedness: "a group that rises as a result of the ruling political party". This issue, is a debate in the state- ruling class involvement literature. Whereas Orthodox Marxist Theory (1968) claims that state is an instrument of the ruling class, serving its interests; Instrumentalist view suggests that in order to maintain order and protect legitimacy, state has to be neutral. The relative autonomy theory (Miliband 1969: 5-7, 150-153, Poulantzas 1975:14-16) argues that state holds relative power against the ruling class. Our findings are largely supportive to the relative autonomy theory: State and ruling class has a delicate balance in their relations where both parties both try to manipulate the other and to preserve own stakes.

Other respondents provided us with different ideas and they defined ruling class from distinct points of view.

I think of ruling class in two dimensions, as I said before, we can consider it as being capital ownership and as a dominant mentality about the approach towards management. (Perran, businesswomen, academist)

This respondent agreed the most common description of ruling class. Domhoff (1999: 267) defined ruling class as the upper class that holds a disproportionate part of wealth. But also, she (Perran) offered a new dimension: "a dominant mentality about the approach towards management". She implied the prescriptive style of management (Special ways and approaches used) practiced by ruling class. By using the same set of practices, other businesses conform the ruling class and also serve their interests. This is also a finding that supports the dominant ideology thesis.

In every city, in the business circle of that city there are unwritten rules ... doyenne businessmen come together, they are wise men, they are men who are decent, respectable men, money is not important for them, the services that they provide to the community, that matters to them... they come together and 
exchange ideas about the latest issues about politics, economics and business. (Seyhan, factory owner)

This respondent avoided describing ruling class from a financial (Capital based) point of view. He continously argued that being a rich businessman does not necessarily mean to be a member of the ruling class. He characterized the ruling class members as being honest, hardworking and highly respected men who serve their community. He also described them as being members of respected families. This finding was convenient with Weber's (1979) argument: He suggested that people who hold a high status in the society based on their family roots keep their positions even after they loose their wealth.

Seyhan also added that those men should have a religious faith, no matter which religion they are related to.

These individuals, from which religious faith they are. religion is not important, they should also have faith in God, even if they do not have, but religion is still an agent. Talking about religion I do not mean being a Muslim or a Christian, but religion is important, he does not have to pray, but he can still be faithful, if he is honest, virtuous, he is faithful for us, there is no scientific measurement for it. (Seyhan, factory owner)

Another respondent told the history of the ruling class that was formed by Atatürk after the foundation of the Turkish Republic.

For the development of Turkey, they needed manufacturers, industrialists; some people accepted to do this, Atatürk gave them the opportunity and the factories. They worked hard and became the rich of the republic. (Salih, brand consultant)

As suggested by Marx and Engels (1979: 64-65), social classes are involved in different means of production. At the beginning of the young republic, all factories were left derelict and dormant, thus the founders had selected a group of people who were willing and able to run those facilities in order to serve the country. The only criterion for selection was not willingness or ability. They selected those people that shared their believes. They were the right men to maintain the new system and disseminate ideas to subordinate classes (Kongar 1998).

Another respondent described ruling class as mainly composed from long standing, deep rooted families. 
But if we think of the ruling class in the business, mostly there are serious family businesses, even though they do not follow corporate management principles, they are the leading power in our economy now. (Perran, businesswomen, academist)

Although no other respondent made this description, virtually all of them mentioned the names of certain families that are seen as strong members of the ruling class in the country.

On another focal point of the research, namely, the factors that shape membership to the ruling class, are declared by the respondents as:

Being part of certain social surroundings; particular educational backgrounds; membership in ruling families; being selected by powerful foreign actors of the global business circles as partners in business; the system, governmental promotions and protective policies practiced in 1960s.

I think that people who have a certain education level, passed through certain experiences are included in this class.. and also I think that social surroundings have important impact on the issue... there may be exceptions but people who come from certain families, social surroundings and education rise easily because they have a better starting point. (Nazan, diplomatist)

Globalization brings big multinationals to Turkey, the investments they make here and their selection of partners for their investments is an important factor. The partnerships they make and their direct investments strengthen some groups...considering Turkey, the most influential factor is politics, the change of ruling party, strengthen some groups. (Kemal, businessman)

Tools used by the ruling class to sustain power and influence: Most respondents named the media and capital (the power money provides to its beholder) as the major tools of ruling class. Other ideas were: Unemployment (the fact that ruling class is the primary employment source, becomes a power tool for them), connections and networks in the business circles, the education institutions (powerful groups establish foundation universities which become a tool for them to practice power and spread their belief systems and life styles), social responsibility projects, involvement with political parties, involvement with the governing political party, the monetary and intangible support they provide to politicians and magazines that show and promote the life styles of the ruling class family members.

Well basically media, which is very current, they use the media, besides, the connections in the business circles, also connections with the state, and also 
now, the business society has stepped into the education system, they use education. In order to keep their position in the ruling class and to train the relevant white collars for themselves, they shape their needs initially and to hire the personnel, they use the education system. They have their own foundation universities they also work on lower education. (Nazan, diplomatist)

They use politics which is natural, this is the way it goes all around the world, they try to direct and influence politics, even though they can not do it as well as they wish all the times. They donate to political parties. They have their own aims, they make the people who can help them reach their aims to take positions in politics, they try to make them elected to the office. Every one supports their own ideas of course. (Nazan, diplomatist)

Tools, their tools are again the media, politics, advertisements, which can be considered as a part of the media, also, social responsibility projects can be named as tools, they even use those projects. Nowadays every company that has a certain size tries to be a part of those projects. They use their own preferences, their tendencies, even that is directing. (Nazan, diplomatist)

One of the major problems of our country is unemployment, we have a huge population, a very young population, so those groups that hold the power are the biggest employers. Consequently they have a big power. I think that they use this as a threat. (Kemal, businessman)

Needless to say that, the money spent during election campaigns, the support needed during that process... The group that supports them during the election campaigns is recompensed. The same is true everywhere. In fact it is even more obvious in the USA, because they whip round for subscription for their campaigns. (Kemal, businessman)

Tthe core tool they have is their capital, if they keep it strong it becomes the basic tool, besides the media groups they own or have close connections with ... One more thing is, although it may not be as effective as the others, the social responsibility projects respected by the community, the ruling class sustains its influence through CSR projects, sponsorships ...the universities founded by those groups recently, these universities substantially represent that group's stand point. (Perran, businesswomen, academist)

The state apparatuses make the dominant ideology reproduce itself by using some channels one of which is media. Also, according to the Relative Autonomy Theory, when state starts to abuse its relative autonomy against ruling class, ruling class counterattacks (Aron 1950: 2-5, 9-14, Miliband 1969: 5-7, 150-153, Poulantzas 1975: 14-16, Giddens 1987: 9). 
The instruments they use are the tools that emerged in our findings. Ruling class uses these tools to stalemate and manipulate the state; sustain and maintain its rule; prevent possible opposition to itself and to disseminate its own belief system. Ruling classes have class consciousness, thus they watch their interests; even when they have no class consciousness, they still protect their stakes as capitalists (Aron 1950: 2-5, 9-14, Miliband 1969: 57, 150-153, Poulantzas 1975: 14-16).

Instrumentalists name influence as the core of ruling class control of state. In capitalist regimes, ruling classes use this influence through the capitalist dynamics: As they hold the power of investment, they can drive the state to corner by avoiding investment. The resulting economic condition that includes a decrease in economic growth and unemployment costs the state a fall in popularity.

The diagram presented below shows the tools which are suggested by the respondents.

Figure 1. Star Diagram

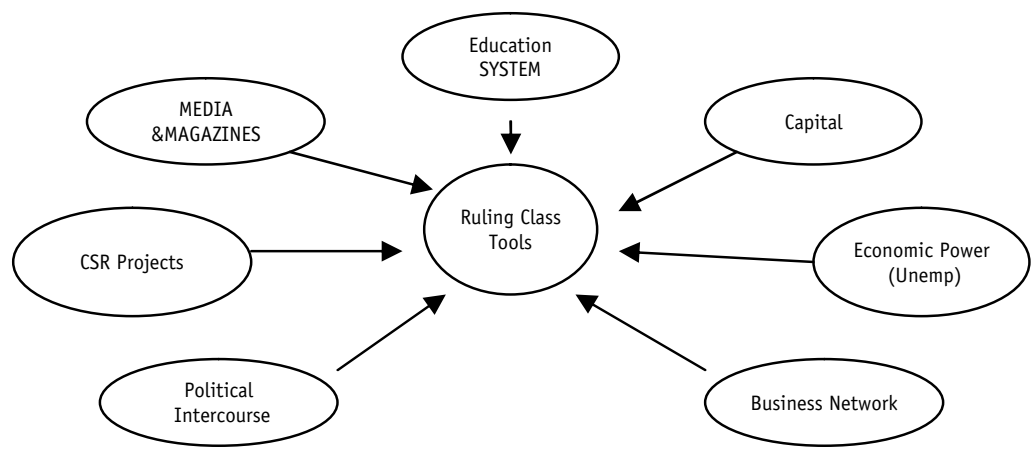

Women's underrepresentation in ruling class: Most of the respondents delivered opinions in favor of the highly faint and inadequate presence of women in the ruling class.

Women's position in the ruling class... that is something that needs quite a correction. (Sinan (CEO)

There are strong woman members of the ruling class, but again, I don't think that they are the majority, I don't think they are as many as they should be. (Nazan, diplomatist) 
Let's not consider the ruling class merely as the business ruling class, let's consider it as ruling the country, lets look at the parliament, lets look at the women congressmen, the number of existing women congressmen is a result of enforcement... Political parties take advantage of the issue, they use it as some kind of advertisement, like saying look we have women among us, we respect them. (Kemal, businessman)

The various reasons reported by the respondents for the weak representation of women are:

The lack of educational opportunities provided for the women; the stereotyped social roles assigned to women which are limited to motherhood and wifehood; the bias women face during their career steps and the inequality they have to fight against in the society.

Even today the average wages for women are less than for men, the managerial positions that women hold are not equal to that of man... in fact its related to education, because average education level for women is much less than men, this is indeed upsetting. (Sinan, CEO)

We observe that they are increasingly influential in the third generation.. even though the pattern is hopeful we still wish we could be in the higher positions. (Perran, businesswomen, academist)

One divergent opinion was declared by a respondent regarding this weak representation as women's own preference to neglect their careers for the sake of their families and children.

It is not old, I mean women are not having the opportunity for education for a long time... they do not have many possibilities, and there is a bias ...besides they have a motherhood duty, even though no one forces them to do so... this hampers their career.. and there are roles tailored for them by the society, you can extend them only to a limit. (Nazan, diplomatist)

Leaving the career for motherhood duty, is not an obligation for the women in Turkey. As stated by Aycan (2004: 456), women usually have a strong family network to rely on when it comes to child care; when a family network is not present, finding inexpensive labor as nannies is easy and widespread. So, a number of distinct examples of voluntarily selecting motherhood over career, can not lead to name it amongst the reasons of women's undersrepresentation in ruling class.

B. Changes in the ruling class: There is a prominent change in the ruling class according to the respondents. They reported three major types of changes:

1. A growing domination of Islamic capital in the business circles. 
2. Changing generations in the management of big family owned corporations.

3. Emergence of a group of capital holders whose roots are unknown and whose sources of richness are shady.

The owners of Islamic capital are increasingly being effective in the business circles and some are already members of the ruling class. Respondents reported that the Islamic ideology groups and the ruling Islamic government have promoted and supported the growth and effectiveness of Islamic capital holders.

Well of course there is an Islamic capital in question, that definitely brought substantial changes. In the past there was not such a vast Islamic capital dominance, what we call the green capital has emerged in the past 10-15 years. The beginning is earlier of course, but it strengthened in the past years. The change of the ruling political party had direct influences on the issue. It was something that has been long prepared; they have strong support.... The whole ruling class has not changed, but there is substantial entry from the owners of Islamic capital. (Nazan, diplomatist)

As I motioned earlier, ruling class... new actors emerged and some has disappeared and some has kept their positions. (Kemal, businessman)

As I said, there is a change in between generations, and emergence of the green capital lately; some of them are from Anatolia and some are there because the winds carried them through. (Perran, businesswomen, academist)

No.. not at all. haaa.. the ruling class definition, if we mean the capital holders, they are changing, in the past Koc had the money, now a man who is known by nobody has multi millions in the bank... but the ruling class that is not dependent on money, has not changed because ethics is important over there, relationships, networks are important. (Seyhan, factory owner)

Seyhan said that there has been a change in the capital structure in the country and some people who have earned money through questionable means have emerged, those people have a false belief that they can buy everything and be respected because of their monetary power. This respondent divided the ruling class to two: One is the group who holds the capital power and this group is reported to have changed recently; the other group- the real ruling class- who holds the intellectual power, knowledge-based power, respect and reputation kept its structure and did not change.

These findings confirmed the theory that like in any other class, the members of the ruling class also change over time (Giddens 1987: 9, Pareto 1935: 1419, 1421, 1424). This is what Turkish ruling class has been facing for the past fifteen years: 
The new capital holders, they do not know how to behave in social events... contrasting them with the existing members, they do not have the manners. (Salih, brand consultant)

As stated by Weber (1979), new money is often insulted by long standing wealth owners, which is the case in this respondent. He talked about this issue in length and said that new entrants do not have the experience and good manners that are required in the social surroundings.

C. State - ruling class involvement: Almost all respondents described organic ties between government agencies and ruling class members. The findings presented the results that governments have a desire and effort to form and control the ruling class via subsidies and education; also, the governing political parties are reported to strive to place their proponents into this class.

State is closely related to the ruling elite, it is a part, because of the education system, plus if you think of the government as the shaper of the business circles, it includes the state... the children of government managers rise easier in the business circles. (Nazan, diplomatist)

I think that the ruling class, at least, has a structure that prevents it from contradicting with the state in order to survive. Because state has a power to influence many things in economics, politics. (Perran, businesswomen, academist)

The above quotations support Domhoffs (1999: 266) statement about the state-ruling class involvement: "How else, it would have been argued, could a tiny group possess so much if it didn't have its hooks into government?"

As referred to in the literature, ruling class counteract to government's actions through certain mediums like lobbying, donations, recruiting ruling class representatives to government positions, influencing policy making processes and favors to political parties and government employees (Aron 1950: 2-5, 9-14, Giddens 1987: 9) These findings confirm the theory in the sense that the ruling class-state involvement is multifaceted in Turkey, too. Listed by Domhoff (1999: 268), the ruling class is involved in the government through several processes:

- The special-interest processs: Serving their short run, immediate interests

- The policy-planning process: Developing policies that serve ruling class interests.

- The candidate-selection process: Ensuring easy access to the elected politicians when needed. 
- The ideology-process: Establishment and expansion of sets of beliefs and attitudes that serve ruling class interests and maintain their power,

which have all been mentioned by the respondents.

\section{Conclusions}

This study originated from the idea that changing political equilibrium in Turkey may have caused a change in the ruling class profile in business circles. The Islamic political parties and Islamic capital groups have consolidated their ever increasing existence in politics and economics; accordingly a respective existence in the ruling class was not so unanticipated. With this study, we hoped to show this change with a perspective from the Eagean Region and the dynamics behind it.

The paper attempted to contribute to the literature by:

1. Presenting the nature of ruling class in Turkish business circles: The respondents offered various definitions and they have described the ruling class from their personal perspectives. All respondents tended to accept the presence of a dominant ruling class. Some described it as a mentality of management, some associated it with politics, some reported that money is the basic requirement for membership of this class. On the other hand, some suggested that honesty, hard work, religious faith and belonging to certain families are the requirements. One respondent also noted that the existing ruling class is purposefully created by the founders of the republic in 1920s.

2. Presenting the set of tools used by the ruling class to ensure the sustainability of their positional power, as offered by the respondents. This set of tools included capital, media, education system and foundation universities, social responsibility projects, unemployment threats based on the major employer status of this class, connections in the business circles, involvement with political parties and even illustrated magazines that promote the ruling class members' life styles.

3. Presenting the position of women in the ruling class: Respondents mostly tended to see this presence as weak and inadequate. The reasons of this underrepresentation were mainly the social roles given to women, women's own choices to stay back and care for their families, inequalities in educational opportunities and unequal treatment among genders in the workplace and in the society.

4. Presenting the change in the Turkish ruling class: Most respondents stated that they observed prominent changes in the member profile of this class. This change had three facets: The emergence and increasing strength of Islamic capital groups, the transfer of power from one gen- 
eration to another, the change of capital holders: The emergence of new Anatolian based capital.

Besides these contributions, findings presented information about ruling class involvement with the state. Respondents mostly tended to tie the ruling class to government. Some stated that ruling class always sustains close relations with government officers and offices; while some argued that ruling class members only try to avoid confronting the government.

The findings exhibited in the paper serve all interested parties in the sense that they help clarify the nature of Turkish ruling class in business circles by providing its description, tools of threat and forming dynamics. And it also serves by heralding and attracting attention to the prominent change of profile in this class alongside with the direction of this change. As the study detects and organizes respondents' perceptions, ideas and experiences in their special situations, conditions and in a specific time frame, it can lead to a better understanding and to better interpretations (Ger 2009: 1-19). In this manner, the paper is expected to contribute the field by attempting to provide a clear shot of the ruling class of today in Turkey from the Eagean Region.

On the other hand the paper has a number of limitations. As stated earlier in the methodology section, as a result of the profiles of respondents (They were all holders of important and critical positions in various institutions), some of the interviews were not as long as intended, thus some available information may have been excluded due to time limitations. As the respondents were from the West Coast of Turkey (Namely, the Eagean Region), the ideas, perceptions and experiences of the rest of the country are not included in the study. The same study can be conducted in other parts of Turkey with respondents from key positions in key institutions with a greater sample in order to ensure involvement of a vast variety of points of view.

\section{References}

Abercrombie, Nicholas and B. S. Turner (1978). "The Dominant Ideology Thesis". The British Journal of Sociology 29 (2): 149-170.

Aron, Raymond (1950). "Social Structure and the Ruling Class: Part 1". The British Journal of Sociology 1 (1): 1-16.

, (1950). "Social Structure and the Ruling Class: Part 2". The British Journal of Sociology 1 (2): 126-143.

Aycan, Zeynep (2004). "Key Success Factors for Women in Management in Turkey". International Association for Applied Psychology. Published by Blackwell Publishing.

Block, Fred (1977). "The Marxist Theory of the State". Socialist Revolution 33: 6-28. 
Bulut, Osman (2012). "Osmanlı Ekonomi Politiği'ne Yeniden Bir Bakış". bilig 62: 63-96.

Domhoff, William G. (1999). "State and Ruling Class in Corporate America". Critical Sociology 25: 266-277.

Ger, Güliz (2009). "Tüketici Araştırmalarında Nitel Yöntemler Kullanmanın İncelikleri ve Zorlukları”. Tüketici ve Tüketim Araștırmaları Dergisi, 1 (1): 1-19.

Giddens, Anthony (1987). Social Theory and Modern Sociology. Polity Press: Cambridge, in association with Basil Blackwell.

Goldthorpe, John H (1968). The Affluent Worker in the Class Structure. Cambridge: Cambridge University Press.

Heper, Metin (2000). "The Ottoman Legacy and Turkish Politics". Journal of International Affairs 54 (1): 63-82.

Ínalcık, Halil (1964). "The Nature of Traditional Society: Turkey". Political Modernization in Japan and Turkey. Princeton University Press.

Kongar, Emre (1998). 21. Yüzyılda Türkiye. Remzi Kitabevi.

Lorasdağı, Berrin Koyuncu (2010). ”The Relationship Between Islam and Globalization in Turkey in the Post-1990 Period: The Case of MÜSİAD”. bilig 52: $105-128$.

Marx, Karl (1968). "The Eighteenth Brumaire of Louis Bonaparte”. Karl Marx and Friedrich Engels, Selected Works. London: Lawrence and Wishart.

Marx, Karl and Friedrich Engels (1979). The German Ideology. London: Lawrence and Wishart.

Miliband, Ralph (1969). State in Capitalist Society. Weidenfeld \& Nicolson. London.

Pareto, Vilfredo (1935). The Mind and The Society. Harcourt: Brace.

Poulantzas, Nicos (1973). Political Power and Social Classes. NLB: And Sheed and Ward. (1975). Classes in Contemporary Capitalism. London: NLB.

Spiggle, Susan (1994). "Analysis and Interpretation of Qualitative Data in Consumer Research". Journal of Consumer Research 21: 491-503.

Weber, Marx (1979). Economy and Society: An Outline of Interpretive Sociology. Berkeley: University of California Press.

Wright, Erik Olin (1978). Class, Crisis and the State. London: New Left Books. , (1985). Classes. London: Verso. , (2000). Class Counts: Student Edition. NY: Cambridge University Press. 


\section{Ege Bölgesinden Nitel Bir İnceleme: İş Dünyasının Deg̃işen Hakim Sınıfı}

\section{Ela Burcu Uçel*}

Alev Katrinli**

Öz

Bu çalışma Türkiye'de iş dünyasındaki hakim sınıfı ve son on beş yılda bu sınıf mensuplarında olması muhtemel değişimleri araştırmayı amaçlamaktadır. Çalışmada 2002 genel seçimlerinde iktidar partisinin değişmesi ve İslami düşünce kökenli bir partinin - Adalet ve Kalkınma Partisi (AKP) - görevi devralmasının ardından Türk siyasi yaşamında gözlemlenen değişimlerin Türk iş dünyasındaki hakim sınıf profiline muhtemel etkisi, Ege Bölgesi'nde iş dünyasının etkin mensuplarından oluşan bir örneklem üzerinde yapılan derinlemesine görüşmelerle incelenmektedir. Bulgular hem hakim sinıf profilinde bir değişime işaret ederken hem de bu sınıfın bir tanımlamasını sunmaktadır.

\section{Anahtar Kelimeler}

Hakim sınıf, işletme, politika, Türkiye, İslami kapital, kadın

İzmir Ekonomi Üniversitesi - İzmir / Türkiye

elaburcy@yahoo.com

** Prof. Dr., İstanbul Aydın Üniversitesi, İktisadi ve İdari Bilimler Fakültesi - İstanbul / Türkiye

katrinli.alev@gmail.com 


\title{
билиг
}

\section{чественное исследов ние гейского регион : изменившийся господствующий кл сс делового мир \\ л урджу чель* лев тринли **}

\begin{abstract}
Аннотация
т р бот призв н исследов ть господствующий кл сс в мире бизнес урции и возможные изменения предст вителей этого кл сс в последние пятн дЦ ть лет. $\mathrm{p}$ ссмотрено возможное влияние политических преобр зов ний турецкой жизни, последов вших после изменения пр вящей п ртии в урции в результ те всеобщих выборов в 2002 году и приход к вл сти п ртии с происл мскими корнями - ртии спр ведливости и $\mathrm{p}$ звития ( ), н профиль господствующего кл сс турецкого мир бизнес н примере углубленных интервью, проведенных с влиятельными предст вителями делового мир гейского регион урции. езульт ты ук зыв ют к к н изменения профиля господствующего кл сс, т к и д ют определение этому кл ссу.
\end{abstract}

\section{Ключевые слова}

господствующий кл сс, менеджмент, политик , урция, исл мский к пит л, женщин

** проф.док. т мбульский университет йдын, ф культет экономических и дминистр тивных н ук т мбул/ урция katrinli.alev@gmail.com 